\title{
Hemotoxic and wound healing potential of coelomic fluid of sea-star Astropecten indicus
}

\author{
Mansi Baveja, Angshuman Sarkar and Dibakar Chakrabarty ${ }^{*}$
}

\begin{abstract}
Background: The coelomic fluid of echinoderms bathes all the internal organs and is a natural reservoir of various bio-active compounds. However, coelomic fluid from Indian sea-star Astropecten indicus is not well characterized for its biochemical and pharmacological profiles. Sea-star (or starfish) Astropecten indicus was collected from the coast of Goa, India during low tides. Sea-star coelomic fluid (SCF) extracted from the sea-stars was concentrated, filtered, and assayed for various hemotoxic activities such as fibrinogenolysis, fibrinolysis, hemolysis, and effects on platelet aggregation.

Results: Studies on effects of SCF on A-549 human lung cancer cell line showed its non-cytotoxic and wound healing abilities in vitro. SCF was found to possess fibrinogen and fibrin digesting ability at a dose of $4 \mu \mathrm{g} / \mathrm{ml}$ within 30 min of incubation with the substrate. Additionally, SCF could hemolyze goat RBC by $50 \%$ and human RBC by only $5 \%$. SDS-PAGE analysis showed that SCF contains various proteins and peptides. Two protein components of SCF yielded strong fibrinolytic, fibrinogenolytic, caseinolytic, and gelatinase activities as revealed by zymography. SCF enhanced the aggregation of ADP and collagen-activated platelets in a dose-dependent manner and had a specific proteolytic activity of $2.5 \mathrm{\mu g} / \mathrm{ml}$ in $30 \mathrm{~min}$ at $37^{\circ} \mathrm{C}$ as assayed using azocasein as substrate.
\end{abstract}

Conclusion: This study focuses on the anticoagulant, pro-platelet aggregation and cell proliferative potential of SCF in vitro and is the first report on hemotoxic and wound healing potential of coelomic fluid of Astropecten indicus.

Keywords: Coelomic fluid, Fibrinogenolysis, Fibrinolysis, Hemolysis, Wound healing, Cell proliferation

\section{Background}

More than $70 \%$ of the surface of the earth is covered with water and has an immense biomass (Montaser \& Luesch, 2011; Newman \& Cragg, 2014). It is well known that the marine environment, despite having an infinite scope for exploration, has been one of the most underutilized biological resources. It contains a vast array of organisms with unique biological properties which could provide a vast resource to combat major diseases (Cardoso, Costa, \& Mano, 2016; Vinothkumar \& Parameswaran, 2013).

\footnotetext{
*Correspondence: diba27@yahoo.com

Some part of this work has been presented by MB in the 22nd meeting of the French Society of Toxinology, Toxins: New Targets and New Functions held in Pasteur institute, Paris, France in December 2014. The abstract was published in special issue of Toxicon titled "Hemotoxic Activity of Sea-star Coelomic Fluid", Toxicon 116 (2016) 72-86

Department of Biological Sciences, BITS Pilani K K Birla Goa campus, NH 17/B, Zuarinagar, Goa 403726, India
}

Terrestrial animals, however, have been exploited for many decades as medicinal resources for the treatment and relief of a myriad of illnesses and diseases in practically every human culture (Costa-Neto, 2005; Montaser \& Luesch, 2011). Marine natural products are now the focus of scientific investigation to discover novel natural products which could be used as medicines (Bordbar, Anwar, \& Saari, 2011).

Members of the class Echinodermata such as the seastars (or starfish) have become virtually a symbol of sea life. They were used in ancient oriental medicine as a source of bioactive compounds and are now used for extraction and purification of cytotoxic, hemolytic, antiviral, antifungal, antifouling, antimicrobial, and even anti-tumoral compounds (Bordbar et al., 2011; Cardoso et al., 2016; Lee, Hsieh, Hsieh, \& Hwang, 2014; Sharmin, 2017; Thao, Luyen, Kim, Kang, Kim, et al., 2014). 
Biochemical and pharmacological profiles of sea-star coelomic fluid (SCF) from Astropecten sp. are not well studied in India and very little effort has been made till now to discover potential drugs from sea-stars (Prabhu, 2013; Dong, 2011).

Anticoagulants and platelet aggregation inhibitors are in high demand due to their ever increasing demand as therapeutic molecules against thrombosis, which is one of the major killer diseases of modern times (Engelmann \& Massberg, 2012; Key et al., 2016; Lau, 2003). In a similar manner, platelet aggregation promoters are also being explored for wound healing and cell proliferation abilities.

In this study, the hemotoxic potential of Astropecten indicus was studied along with its potential to promote cellular proliferation, platelet aggregation, and wound healing in vitro.

\section{Methods}

\section{Reagents and chemicals}

All chemicals used in this study were of analytical grade and purchased from Sigma Aldrich, USA. Protein molecular weight markers were purchased from GeneI, Bangalore, India. Reagents for platelet aggregation studies were purchased from Wheecon Instruments Pvt. Ltd. Reagents for cell culture were purchased from Hi-Media and Sigma Aldrich, USA. Plastic wares were purchased from Tarsons and Corning, USA.

\section{Instruments}

Whole blood platelet aggregometer was purchased from Wheecon Instruments Pvt. Ltd., India. ELISA plate reader for 96-well plates was purchased from Thermo Scientific, India.

\section{Specimen collection}

Live sea-stars of Astropecten indicus species (Fig. 1) were collected from the sea shore of south-Goa, India, during low tides in the months of October and November, when they are abundantly available. The sea-stars were kept aerated in containers of sea water and transported to the laboratory where coelomic fluid was extracted from them.

\section{Preparation of sea-star coelomic fluid (SCF)}

Coelomic fluid was extracted from each sea-star through its aboral pore by syringe aspiration without sacrificing the animals. Care was taken to not extract more than 0 . $5 \mathrm{ml}$ of coelomic fluid from each sea-star so that they are not sacrificed or stressed. The sea-stars were released back into the sea after extraction of SCF. No animals were sacrificed for this study.

The extracted coelomic fluid was pooled and centrifuged at $10,000 \mathrm{rpm}$ for $15 \mathrm{~min}$ at $4{ }^{\circ} \mathrm{C}$ to remove the

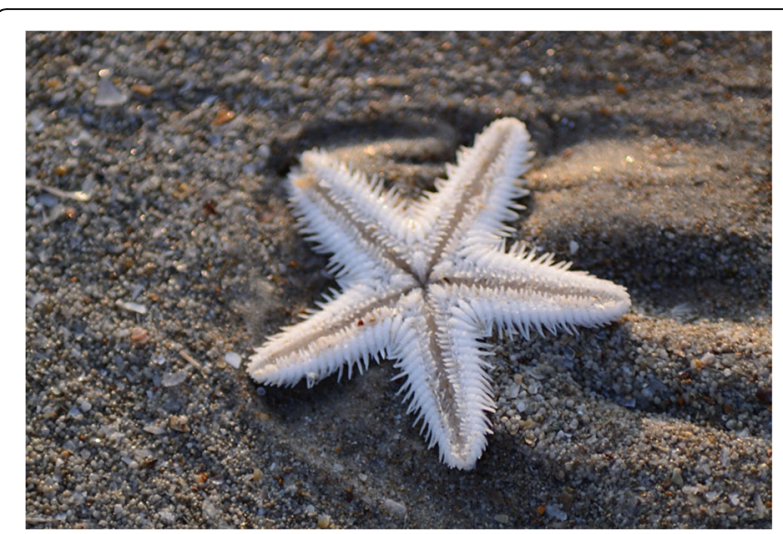

Fig. 1 Astropecten indicus found along the coast of Goa, India. Picture of Asteropecten indicus found in Goa, India. The sea-star was identified as Astropecten indicus by the Zoological Survey of India, Chennai, India

cell debris which settled down as pellet. The supernatant was concentrated by ultra-filtration using a millipore membrane of molecular weight cut-off of $10 \mathrm{kDa}$. The retentive supernatant obtained after ultra-filtration is referred to as sea-star coelomic fluid (SCF) which was used for further studies.

\section{Protein estimation}

Protein content in SCF was estimated using Bradford protein assay (Bradford, 1976). The protein profile of SCF was studied by running SCF in a $12 \%$ SDS-PAGE (sodium dodecyl sulfate polyacrylamide gel electrophoresis) followed by silver staining (Fig. 2).

\section{Assay of fibrin(ogen)olytic activity}

Human fibrinogen was suspended in potassium phosphate buffer (KPB) $\mathrm{pH} 7.4$, and different doses of SCF were incubated with $2 \mathrm{mg} / \mathrm{ml}$ of it for $5 \mathrm{~h}$ at $37{ }^{\circ} \mathrm{C}$. Fibrinogenolytic activity was assessed by running the pre-incubated samples on a $12 \%$ SDS-PAGE. Fibrinogenolytic activity was confirmed by disappearance of one or more chains of fibrinogen observed by coomassie staining of the gel followed by destaining. Fibrinogen $(30 \mu \mathrm{g})$ yielded three protein bands viz. $A \alpha, B \beta$, and $\gamma$ when run on a $12 \%$ SDS-PAGE. SCF upon incubation with fibrinogen led to the sequential degradation of $A \alpha, B \beta$, and $\gamma$ bands in a dose- and time-dependent manner (Figs. 3 and 4), (Chanda, Sarkar, \& Chakrabarty, 2016).

\section{Zymogram assay for proteolytic activity}

Zymogram protease assay was performed to estimate different kinds of protease activities (fibrinolytic, fibrinogenolytic, and caseinolytic as seen in Fig. 5a-c, respectively) of the protein components of SCF. The protein substrate $(10 \mathrm{mg})$ was co-polymerized with acrylamide during preparation of the polyacrylamide gel, followed 


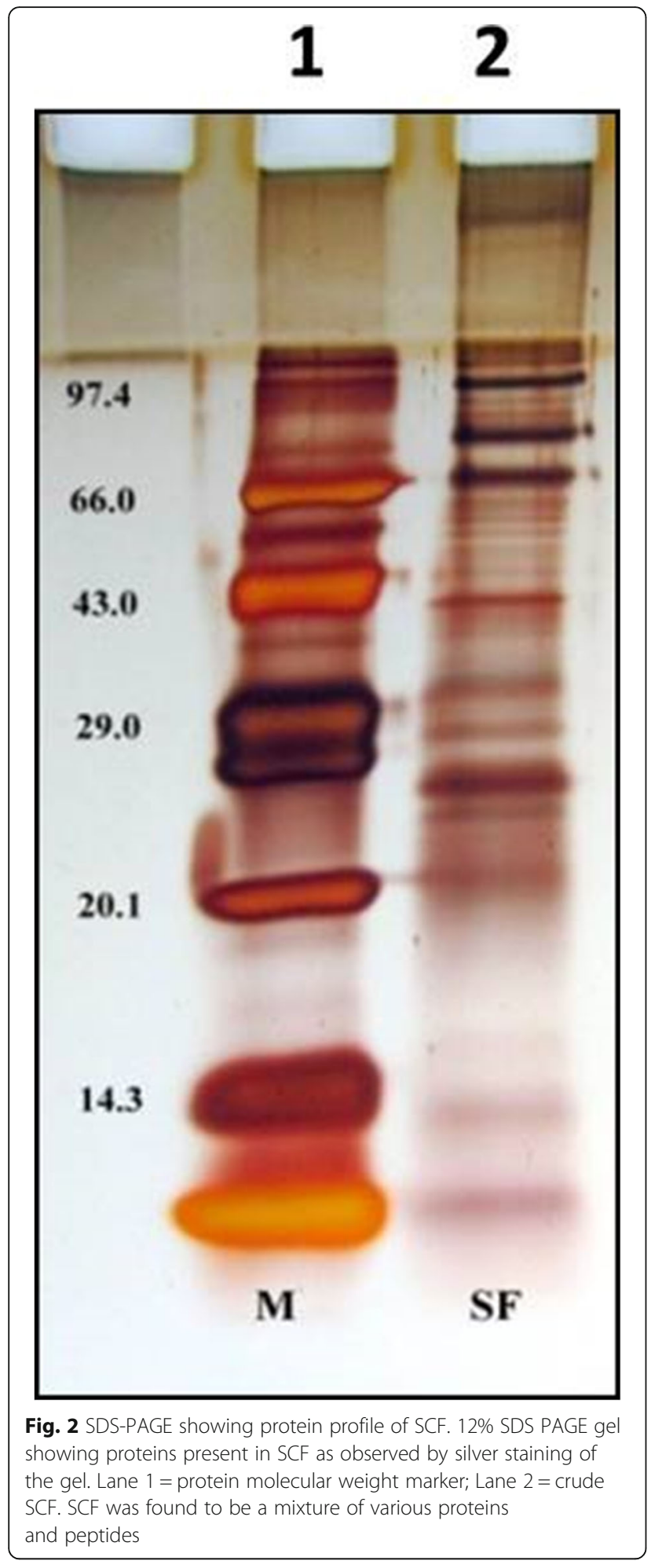

by electrophoresis of SCF $(4 \mu \mathrm{g} / \mathrm{ml})$ on the same gel using native page running conditions. The gel was washed with Triton-X (two times) to remove the SDS and followed by incubation in an incubation buffer of Tris- $\mathrm{Cacl}_{2}$ of $\mathrm{pH} 7.4$ at $37{ }^{\circ} \mathrm{C}$ for varied time periods.
Protease activity of SCF was observed by staining the gel with $1.25 \%$ coomassie followed by destaining with $10 \%$ acetic acid and 10\% methanol in milliQ water. The entire gel was stained with coomassie due to presence of protein substrate embedded in it. Protease activity of the active proteins present in SCF was observed as regions of destained areas on the gel due to digestion of protease substrate by them (Leber \& Balkwill, 1997; Masure, Proost, Van Damme, \& Opdenakker, 1991).

\section{Estimation of proteolytic activity using Azocasein}

Non-specific proteolytic activity of SCF was estimated by using azocasein as substrate. Briefly, $125 \mu \mathrm{l}$ of suitable dilutions of SCF were incubated with $125 \mu \mathrm{l}$ of $0.25 \%(w / v)$ azocasein and incubated for $30 \mathrm{~min}$ at $37{ }^{\circ} \mathrm{C}$. The reaction was terminated by adding $500 \mu \mathrm{l}$ of $10 \%$ trichloroacetic acid to the reaction mixture and vortexed. This was followed by centrifugation at $4000 \mathrm{rpm}$ at $4{ }^{\circ} \mathrm{C}$ for $15 \mathrm{~min}$. Five hundred microliters of the supernatant was neutralized by adding $500 \mu \mathrm{l}$ of $1.8 \mathrm{~N} \mathrm{NaOH}$ and absorbance was measured at $440 \mathrm{~nm}$ using a spectrophotometer. One unit of enzyme activity was defined as the amount of protease which yielded an increase in absorbance of 0.01 in $30 \mathrm{~min}$ at $37{ }^{\circ} \mathrm{C}$ (Secades \& Guijarro, 1999).

\section{Estimation of hemolytic activity}

Hemolytic activity was assayed by incubating varying doses of SCF with $1 \%$ human or goat erythrocyte suspension in $0.85 \%$ saline at $37{ }^{\circ} \mathrm{C}$ for $1 \mathrm{~h}$. Hemolysis was estimated by measuring absorbance at $540 \mathrm{~nm}$ and comparing it with positive control (1\% SDS) which showed $100 \%$ lysis; $0.85 \%$ saline served as negative control (Chakrabarty, Datta, Gomes, \& Bhattacharyya, 2000).

\section{Effects of SCF on platelet aggregation}

SCF was studied for its effects on ADP- and collagen-induced platelet aggregation using Chronolog whole blood platelet aggregometer. Human blood $(9 \mathrm{ml})$ was freshly collected from "O" positive, healthy volunteers with prior and informed consent, in $3.8 \%$ sodium citrate $(1 \mathrm{ml})$ under expert medical supervision. All studies were carried out using the whole blood platelet aggregometer. Blood was incubated with $0.85 \%$ saline (1:1 dilution) in a cuvette for $5 \mathrm{~min}$ at $37{ }^{\circ} \mathrm{C}$. Platelet aggregation agonists ADP $(10 \mu \mathrm{M})$ or collagen $(2 \mu \mathrm{g} / \mathrm{ml})$ added to the above mixture served as positive controls. As a platelet agonist is added to the mixture, platelets aggregate as a monolayer on the electrical probes immersed in the cuvettes. Accumulation of platelets offers a resistance (or impedance) to the electrical circuit which is 


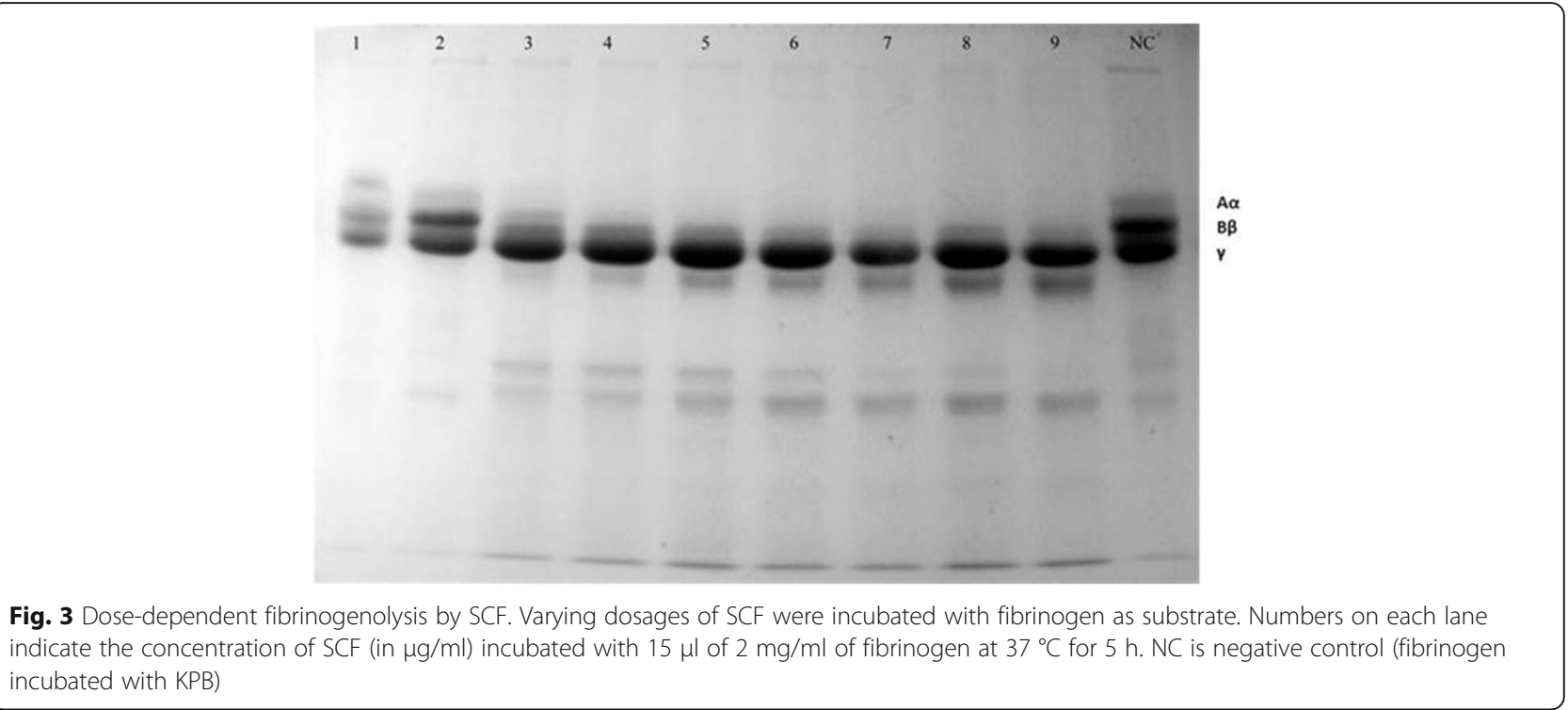

quantified in ohms. Change in impedance is expressed as a function of time. Protein fraction(s) incubated with the blood, saline, and agonist mixture served as test samples. Blood incubated with saline served as negative control. Positive control showed maximum resistance. Negative controls were devoid of any agonists for aggregation and hence offered negligible resistance (Chanda, Sarkar, Sistla, \& Chakrabarty, 2013).

\section{Effects of SCF on A-549 cell line}

A-549 cells (human lung carcinoma epithelial cells) were procured by Dr. Angshuman Sarkar from National
CentrE for Cell Science (NCCS), Pune, India. The cells were cultured in vitro in T-25 flasks in Dulbecco's modified Eagle's medium (DMEM) supplemented with 10\% FBS (fetal bovine serum) and $0.01 \%$ antibiotic and antimycotic solution. The effects of SCF on A-549 cells were studied by observing changes in morphology of A-549 cells, change in viability of the cells after treatment with different doses of SCF using, MTT cytotoxicity assay (Amini, Nabiuni, Baharara, Parivar, \& Asili, 2014; Pathan, Mondal, Sarkar, \& Chakrabarty, 2017) and resazurin reduction assay (Allshire, Anoopkaumar-Dukie, Carey, Conere, Sullivan, et al., 2005; Pathan, Martin, Chowdhury, Chakrabarty, \& Sarkar, 2015).

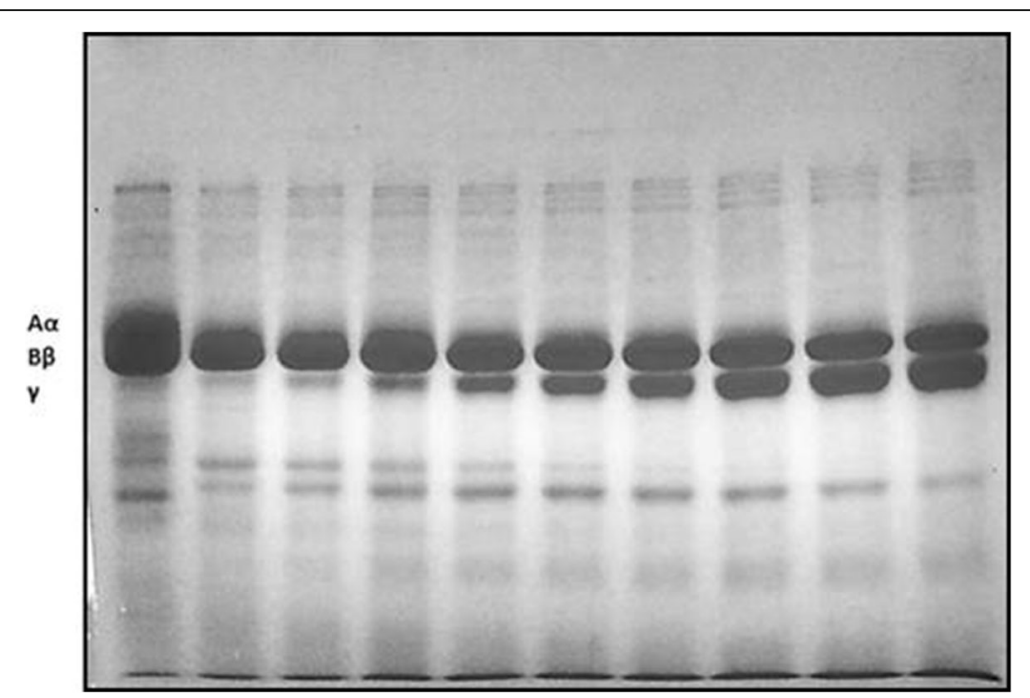

Fig. 4 Time-dependent fibrinogenolysis by SCF. SCF $(4 \mu \mathrm{g} / \mathrm{ml})$ was incubated with $2 \mathrm{mg} / \mathrm{ml}$ of fibrinogen for varied time periods to test the time required by $4 \mu \mathrm{g} / \mathrm{ml} \mathrm{SCF}$ to digest fibrinogen. Numbers on each lane indicate incubation time periods in hours. $C=$ fibrinogen incubated with KPB 


\section{Fibrin}

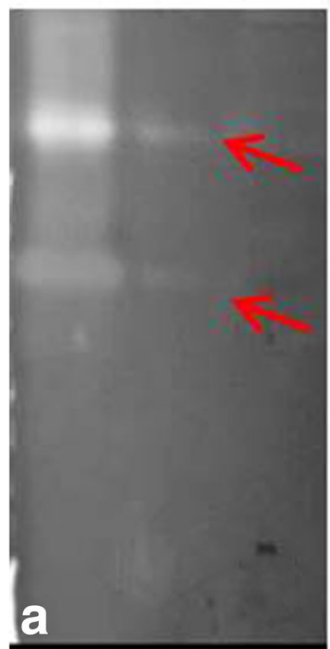

\section{Fibrinogen Casein}
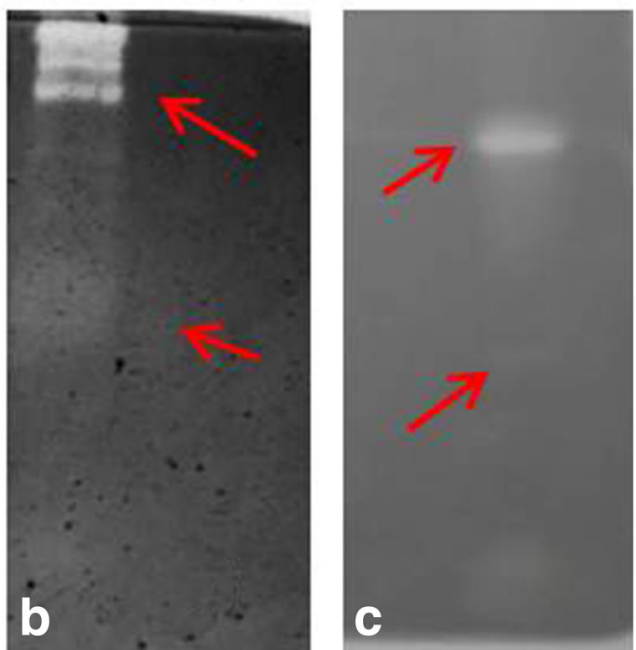

Fig. 5 Proteolytic activity of SCF using different substrates assayed using zymogram protease assay. Arrows in red indicate zones of digestion of protein substrates. a Fibrinolytic activity of SCF. b Fibrinogenolytic activity of SCF. c Caseinolytic activity of SCF. a Fibrinolytic activity of SCF (4 $\mu \mathrm{g} /$ $\mathrm{ml}$ ) was assayed by copolymerizing fibrinogen and thrombin to yield fibrin in the acrylamide gel followed by incubation of the gel in incubation buffer for 1, 2, and $5 \mathrm{~h}$ incubation period at $37^{\circ} \mathrm{C}$. Fibrinolytic activity was observed at all three incubation intervals, seen as digestion of the substrate. The figure shows fibrinolysis by SCF after $1 \mathrm{~h}$ of incubation. b SCF $(4 \mu \mathrm{g} / \mathrm{ml})$ digested fibrinogen copolymerized with the acrylamide gel within $1 \mathrm{~h}$ of incubation at $37{ }^{\circ} \mathrm{C}$. c SCF $(4 \mu \mathrm{g} / \mathrm{ml})$ digested casein present in the polyacrylamide gel seen as destained region of the zymogram gel. Activity was seen within $1 \mathrm{~h}$ of incubation at $37^{\circ} \mathrm{C}$

\section{Wound healing effects of SCF on A-549 cells}

A-549 cells were cultured in vitro in T-25 flasks as described in Section "Effects of SCF on A-549 cell line". Cells were seeded at $70 \%$ confluence in six-well plates at a seeding density of 30,000 cells $/ \mathrm{ml}$ and were left overnight in sterile humified conditions. Upon $60 \%$ cell confluency, the spent media was discarded from the wells followed by washing with phosphate buffer saline (PBS) to remove unattached cells. A longitudinal scratch was made in each well using a sterile $200-\mu l$ pipette tip. The cells were again washed with PBS and $2 \mathrm{ml}$ of DMEM supplemented with $10 \%$ FBS, and $0.01 \%$ antibiotic solution was added to each well of the culture plate. SCF at different doses was added to the well such that the final volume in each well was $2 \mathrm{ml}$. Images were taken for each well at time intervals of $24 \mathrm{~h}$ till $72 \mathrm{~h}$ to observe effect of SCF on the wounds. Area of the wound was calculated using Image software, and wound healing activity of SCF was expressed as the \% wound healed at given time period using initial wound area (0th hour) as reference (Pathan et al., 2017).

\section{Results}

\section{Protein profile of SCF}

Protein profile of SCF was studied by electrophoresis on a $12 \%$ SDS-PAGE followed by silver staining the gel. Many protein bands were observed in crude SCF as seen in Fig. 2.

\section{Fibrinogenolytic activity of SCF}

Fibrinogenolytic activity of SCF was estimated by incubating different dosages with fibrinogen as substrate for varied time periods. It is noted that at low concentrations $(4 \mu \mathrm{g} / \mathrm{ml})$, SCF could digest only A- $\alpha$ chain of human fibrinogen. However, at concentrations of $10 \mu \mathrm{g} / \mathrm{ml}$ and higher, SCF could digest B- $\beta$ and $\gamma$ chains of fibrinogen as well. The fibrinogenolysis could be observed within $30 \mathrm{~min}$ of incubation with the substrate indicating its prompt activity at lower dosages (Figs. 3 and 4).

\section{Zymogram assays for protease activity}

The substrates (fibrin, fibrinogen, and casein) were copolymerized separately with the polyacrylamide gel, followed by electrophoresis of SCF $(4 \mu \mathrm{g} / \mathrm{ml})$. The gel was cut in three parts and incubated for 1,2 , and $5 \mathrm{~h}$ in the incubation buffer at $37{ }^{\circ} \mathrm{C}$. Active proteolytic proteins showed clear digestion of the substrate within $1 \mathrm{~h}$ of incubation. SCF was confirmed to possess fibrinolytic, fibrinogenolytic, and caseinolytic activities (Fig. 5a-c, respectively). Proteolytically active proteins were majorly found around $66-$ and $45-\mathrm{kDa}$ regions of the gel as evident from the figures.

\section{Inhibition of fibrinogenolytic activity}

SCF was treated with various inhibitors such as ethylenediaminetetraacetic acid (EDTA), phenylmethylsulfonyl fluoride (PMSF), and dithiothreitol (DTT) for $2 \mathrm{~h}$ at 
$37^{\circ} \mathrm{C}$ and then assayed for fibrinogenolytic activity using zymogram assay as well as by SDS-PAGE. EDTA was found to completely inhibit fibrinogenolytic activity by chelating the metal ions, indicating the fibrinogenolytically active protein components to be metalloproteinases (Fig. 6).

\section{Proteolytic activity of SCF using azocasein as substrate}

Specific activity of SCF using (azo)caseinolytic activity assay was estimated to be $2.5 \mathrm{\mu g} / \mathrm{ml}$ in $30 \mathrm{~min}$ at $37^{\circ} \mathrm{C}$.

\section{Hemolytic activity of SCF}

Hemolytic activity of SCF was studied on human and goat RBC in a dose-dependent manner. SCF showed hemolytic activity below $5 \%$ on human RBCs at all dosages. A significant hemolytic activity of $50 \%$ in goat RBCs was observed at a dose of $20 \mu \mathrm{g} / \mathrm{ml} \mathrm{SCF}$ (Fig. 7a, b). Low hemolyzing effects of SCF on human RBCs make it a safe candidate for drug discovery and development.

\section{Effect of SCF on ADP- and collagen-induced platelet aggregation}

SCF was found to promote ADP-induced aggregation of platelets in a dose-dependent manner. SCF could not initiate the activation of platelets themselves. However, they could further aggregate the ADP-induced platelets in a dose-dependent manner. It is noted that SCF inhibited ADP-induced platelet aggregation at doses below $10 \mu \mathrm{g} / \mathrm{ml}$ and caused pro-aggregation at higher doses (Fig. 8). A similar effect was seen in case of collagen-

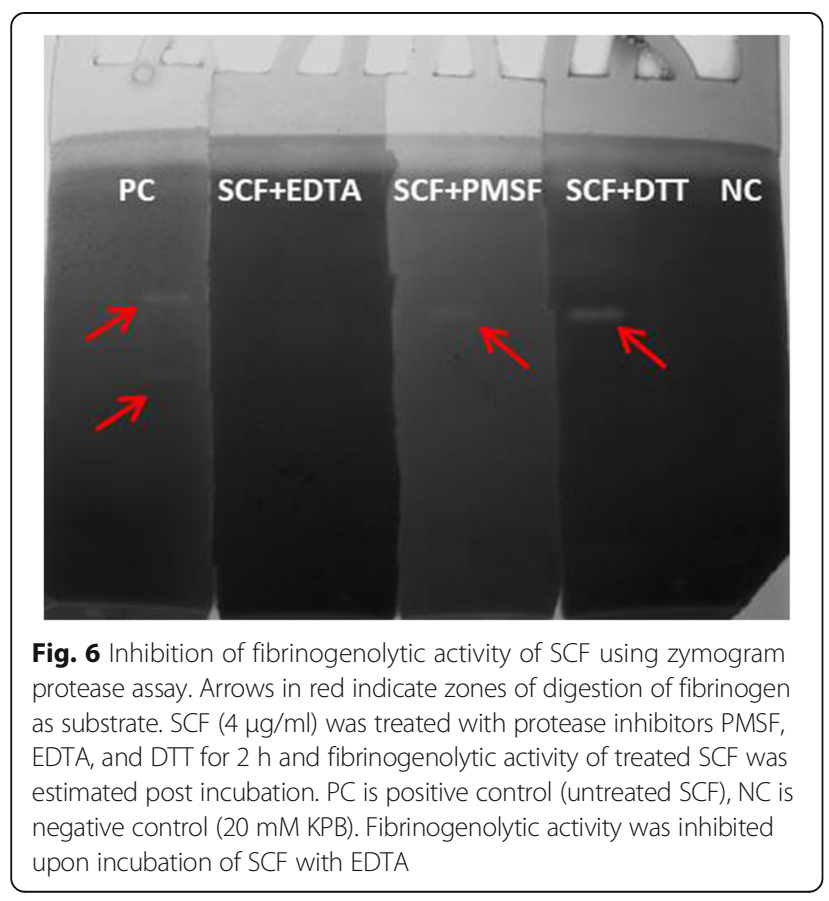

induced platelet aggregation in which pro-aggregation of platelets was observed at SCF concentrations $2 \mu \mathrm{g} / \mathrm{ml}$ and higher (Fig. 9).

\section{Effects of SCF on morphology of A-549 cells in vitro}

A-549 cells were seeded in vitro in six-well plates at a density of 30,000 cells $/ \mathrm{ml}$ and were left overnight in $2 \mathrm{ml}$ of DMEM supplemented with 10\% FBS and antibiotic and antimycotic solution at $37{ }^{\circ} \mathrm{C}$ in a humidified $5 \% \mathrm{CO}_{2}$ environment. Different dosages of SCF were added to each well, and subsequently, morphology of the cells was observed after every $24 \mathrm{~h}$ up to $72 \mathrm{~h}$ post treatment. There were no significant changes observed in morphology of the cells at less than $10 \mu \mathrm{g} / \mathrm{ml}$ dosage of SCF (Fig. 10).

\section{Effects of SCF on A-549 cells}

Effects of SCF on viability and proliferation of A-549 cells was observed in a dose-dependent manner as well. Cell viability of SCF-treated cells was assayed MTT cytotoxicity assay and resazurin reduction assay. It was confirmed that SCF did not cause decrease in viability of the cells when they were exposed to SCF dosages below $10 \mu \mathrm{g} / \mathrm{ml}$ (Fig. 11a, b). On the other hand, significant increase in cell proliferation was observed in treated cells as compared to untreated cells.

Resazurin reduction assay was used to estimate increase in metabolic activity of the cells post treatment with various dosages of SCF (Refer to Additional file 1: Figure S1). It was found that SCF-treated cells were more viable as compared to control (untreated cells). This was estimated by conversion of resazurin to resorufin by metabolically active cells and quantification of resorufin formation by measuring absorbance at $610 \mathrm{~nm}$. Untreated cells were considered as $100 \%$ viable.

\section{Wound healing ability of SCF}

Wounds were created on A-549 cells in six-well plates in vitro. Abilities of different concentrations of SCF to heal the wounds were observed at every $24 \mathrm{~h}$ up to $72 \mathrm{~h}$ post treatment. Wounds were completely healed by SCF within $72 \mathrm{~h}$ of treatment as seen in Fig. 12. Wound healing activity of SCF was quantified using ImageJ software. Results are expressed as percentage of wound healed (Fig. 12a, b). It is noted that the wound area decreased significantly in cells treated with 2.5 and $5 \mu \mathrm{g} / \mathrm{ml}$ of SCF as compared to that in control (untreated cells). This indicated a significant wound healing activity of SCF in A549 cells.

\section{Discussion}

Sea-stars have been studied extensively in the past few years due to their diverse bioactivities and secondary metabolites (Ferguson, 1964; Schillaci \& Arizza, 2013). 

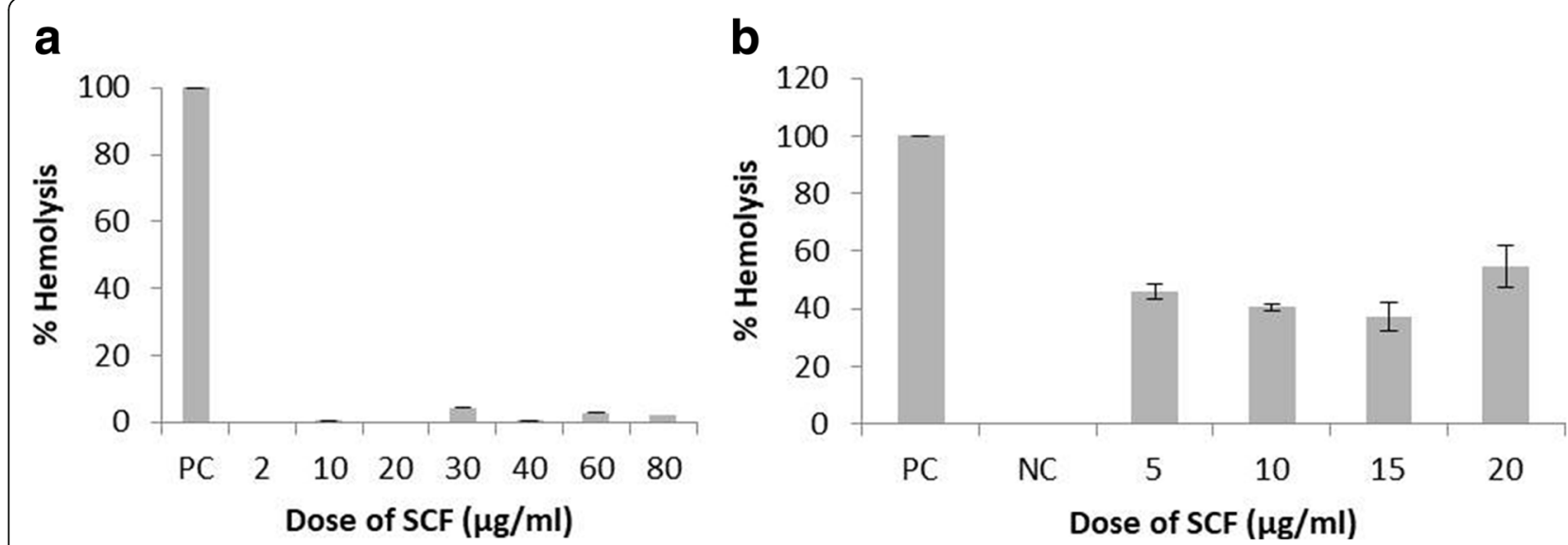

Fig. 7 a Hemolytic activity of SCF on human RBCs. Hemolytic activity of various dosages of SCF were tested on human RBCs. PC $=1 \%$ SDS; NC = $0.85 \%$ saline. SCF showed negligible hemolysis of human erythrocytes in vitro ( $n=3$ replicates). $\mathbf{b}$ Hemolytic activity of SCF on goat RBCs. PC $=$ $1 \%$ SDS; NC $=0.85 \%$ saline. Hemolytic activity of SCF on goat RBCs was much higher compared to human RBCs ( $n=3$ replicates)

Astropecten indicus have been reported for their antimicrobial potential (Chamundeeswari, 2012). However, their hemotoxic and anticoagulant nature has not been reported so far. The coelomic fluid bathes all the internal organs of sea-stars and is a rich source of growth factors, hormones, proteins, and peptides involved in cell signaling. Coelomic fluid from sea-stars Astropecten indicus was studied for various hemotoxic activities in vitro. It lysed human fibrinogen $(30 \mu \mathrm{g})$ at a concentration of $4 \mu \mathrm{g} / \mathrm{ml}$ within $30 \mathrm{~min}$ of incubation with the substrate. Other proteolytic activities of SCF such as fibrinolytic, fibrinogenolytic, and caseinolytic activities were also observed at this concentration (Fig. 5). Significant fibrinogen digesting potential of SCF at such low concentration indicates the presence of potent anticoagulants which need to be further purified and characterized. EDTA inhibited fibrinogenolytic activity of SCF by chelating the metal ions, indicating the active protein components to be metalloproteinases (Fig. 6). Specific protease activity of SCF using azocasein was estimated to be $2.5 \mu \mathrm{g} / \mathrm{ml}$ in $30 \mathrm{~min}$ at $37^{\circ} \mathrm{C}$. Hemolytic activity of SCF on human RBCs was below $5 \%$ making it a safe

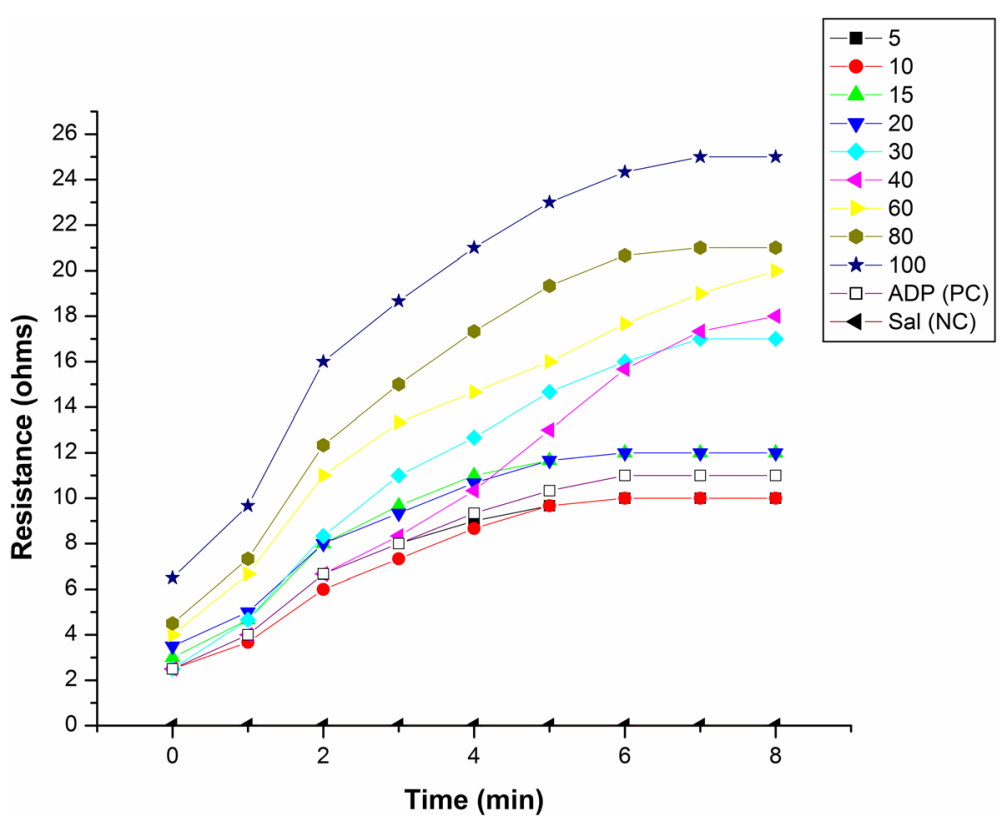

Fig. 8 Effect of SCF on ADP-induced platelet aggregation. Blood was treated with different dosages of SCF and platelet aggregation was induced by ADP and measured using whole blood platelet aggregometer. PC = Blood incubated with saline and ADP; NC = Blood incubated with saline only (no agonist added). SCF inhibited platelet aggregation till a dosage of $10 \mu \mathrm{g} / \mathrm{ml}$ and promoted aggregation at higher dosages in a dosedependent manner ( $n=3$ replicates) 


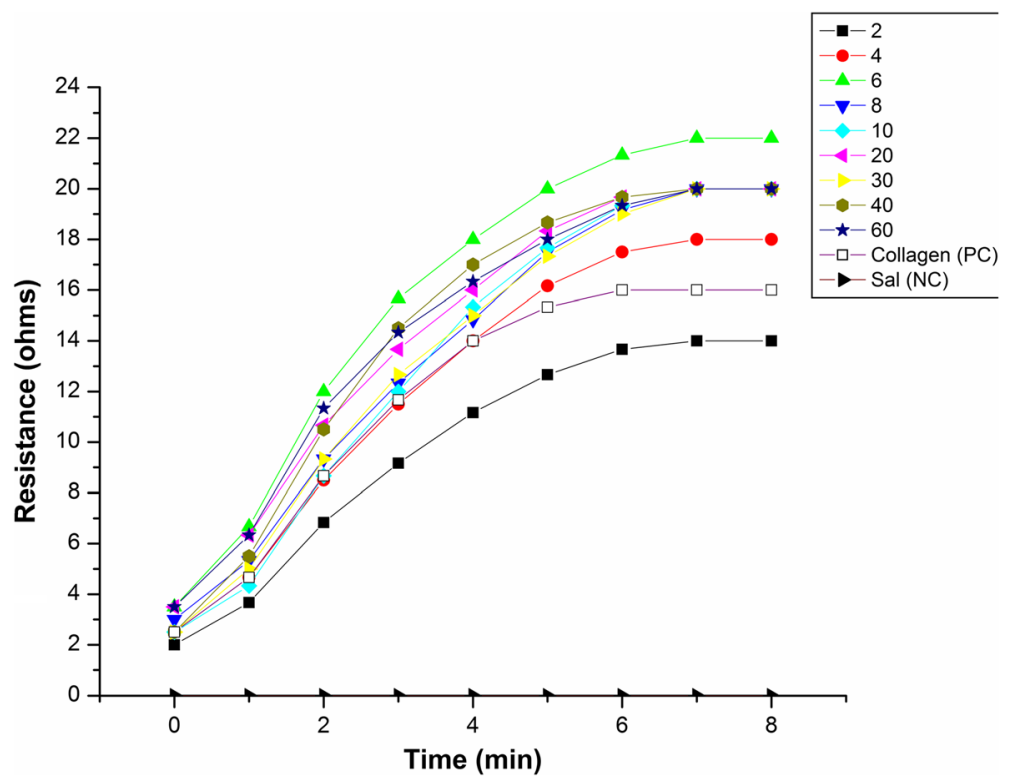

Fig. 9 Effect of SCF on collagen-induced platelet aggregation. Blood was treated with different dosages of SCF and platelet aggregation was induced by collagen. PC = Blood incubated with saline and collagen; NC= blood incubated with saline only (no agonist added). SCF promoted collagen-induced platelet aggregation in a dose-dependent manner starting from $2 \mu \mathrm{g} / \mathrm{ml}$ ( $n=3$ replicates)

candidate for drug discovery. However, it showed significant hemolysis in goat RBCs. These results show the anticoagulant activity of SCF is most effective at a concentration of $4 \mu \mathrm{g} / \mathrm{ml}$ where it shows fibrinogenolytic as well as anti-platelet activity (for ADP-induced platelet aggregation). Platelet adhesion and aggregation are considered as the first physiological responses towards vascular injury which initiate thrombus formation and permit wound healing. Platelet aggregation is initiated post-vascular injury wherein the circulating platelets come in contact with collagen, fibronectin, vWF (von Willebrand factor) A1 domain, and the membrane glycoproteins GPIb $\alpha$ causing platelets to adhere to basement membrane and further initiating recruitment of more platelets to the site of injury to form a platelet plug. Fibrinogen binds to the integrin receptors on activated
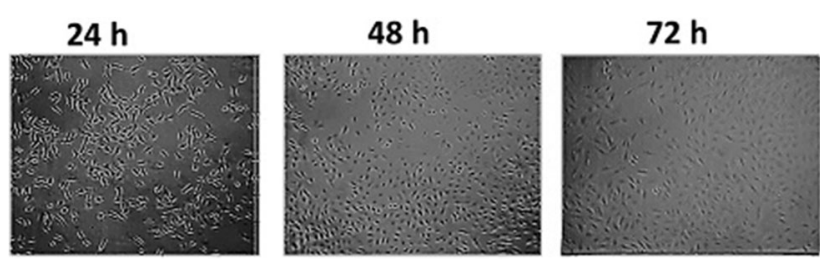

Control
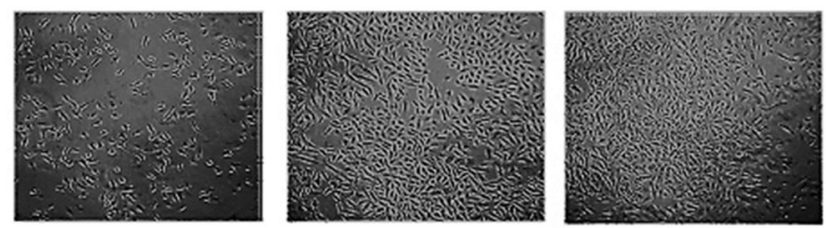

\section{$2.5 \mu \mathrm{g} / \mathrm{ml}$}
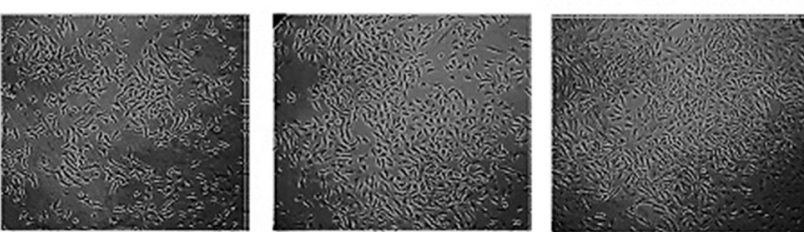

$5 \mu \mathrm{g} / \mathrm{ml}$

Fig. 10 Effect of SCF on morphology of A-549 cells in vitro. A-549 cells were cultured in vitro and treated with different dosages of SCF and cell morphology was observed. Untreated cells served as control. No significant change in the morphology of A-549 cells was observed post treatment with SCF 

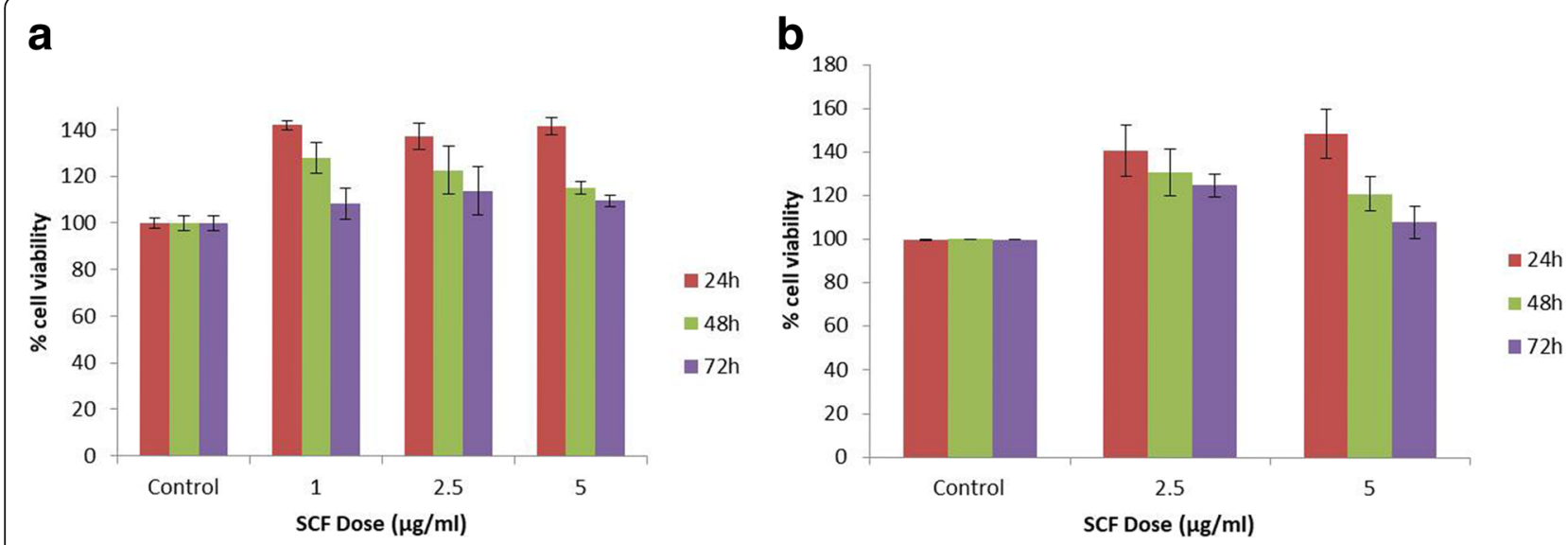

Fig. 11 a Cytotoxicity of SCF on A-549 cells using MTT assay. SCF was tested for its cytotoxicity at different dosages on A-549 cultured cells. Cells were treated with various dosages of SCF for 24,48 , and $72 \mathrm{~h}$. Cell viability was depicted as percentage of viable cells, taking untreated cells served as control (regarded as $100 \%$ viable cells); ( $n=4$ replicates). b Resazurin reduction assay to study effects of SCF on viability of A-549 cells. Effect of SCF on viability of A-549 cells was assayed in a dose-dependent manner. Untreated cells were considered as $100 \%$ viable. Viability of SCF-treated cells were assayed every $24 \mathrm{~h}$ for $72 \mathrm{~h}$ post treatment using untreated cells as reference. Cells treated with SCF actively converted resazurin to resorufin indicating increase in metabolic activity of the cells post treatment; $(n=3$ replicates)

platelets, thereby acting as bridges between platelets to bring about platelet aggregation. Interestingly, SCF at concentrations above $10 \mu \mathrm{g} / \mathrm{ml}$ showed pro-aggregation of platelets with ADP as agonist, whereas proaggregation activity of SCF was observed above $2 \mu \mathrm{g} / \mathrm{ml}$ concentration in collagen-activated platelet (Figs. 8 and 9). SCF is a mixture of several proteins and peptides. Probably, at higher concentrations of SCF, some minor protein components could be reaching a threshold concentration at which they are able to show platelet aggregation activity. This could explain both anti-platelet and pro-platelet aggregating activities of SCF at different dosages. Further purification of these active proteins/ peptides would be useful to decipher the exact mechanism of anticoagulant activity and effects on platelet aggregation.

SCF was found to have no cytotoxic effects on A-549 cells cultured in vitro. Time-dependent increase in cell viability was noted in A-549 cells post-treatment with SCF as confirmed by MTT assay and resazurin reduction assay (Fig. 11a, b and Additional file 1: Figure S1). Exposure of A-549 cells to SCF showed increase in their metabolic activity and conversion of resazurin to resorufin. Increased resorufin production in SCF-treated cells coincided with SCF-induced proliferative activity seen in A-549 cells (Riss, Moravec, Niles, Duellman, Benink, et al., 2016). Complete healing of the wounds created on A-549 cells was observed at the same dose of SCF (Fig.
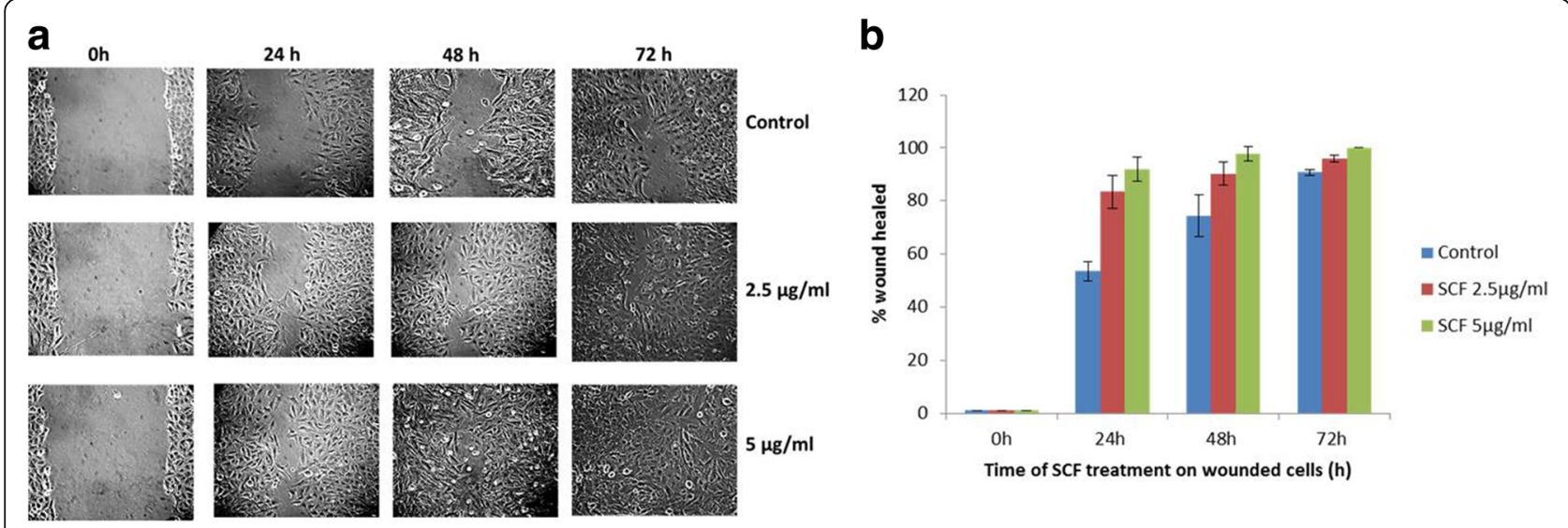

Fig. 12 a Wound healing activity of SCF on A-549 cells. Wounds were created on A-549 cells, and effect of SCF on wound area was estimated. Untreated cells served as control. Wounds healed faster in cells treated with SCF as compared to control; ( $n=4$ replicates). $\mathbf{b}$ Effect of SCF on healing of wounds created on A-549 cells in vitro. Wound healing ability of SCF was quantified as the \% area of the wound healed by different dosages of SCF using ImageJ software. Wounded cells treated with DMEM served as control; $(n=4$ replicates) 
12) The actual process of wound healing post vascular injury is a systematic process that occurs in four phases: hemostasis, inflammation, proliferation, and maturation (Mercandetti, 2015; Simon, 2015). Platelets play a major role in vasoconstriction and hemostasis which is the first phase of wound healing (Italiano, Richardson, PatelHett, Battinelli, Zaslavsky, et al., 2008). On activation of platelets, many factors are released from dense granules of the aggregating platelets which influence cell migration and proliferation (Golebiewska \& Poole, 2015; Nurden, Nurden, Sanchez, Andia, \& Anitua, 2008).

The two major pharmacological activities found in SCF namely pro-aggregation of platelets and proproliferation and wound healing abilities may be caused by a single factor present in SCF or there is also a possibility that these activities could be due to synergistic effect of several factors. It would be interesting to study the proteins present in SCF separately in different in vitro and in vivo systems.

\section{Conclusions}

We report for the first time, the anticoagulant, cell proliferative, and wound healing potentials of coelomic fluid of sea-stars Astropecten indicus in vitro. The active protein components of SCF are metalloproteinases and are fibrin(ogen)olytically potent at concentration of $4 \mu \mathrm{g} / \mathrm{ml}$. Cell proliferative ability and wound healing potential of SCF is significant at a dose of $2.5 \mu \mathrm{g} / \mathrm{ml}$. The anticoagulant and wound healing potential of SCF of Astropecten indicus at low concentrations makes it a potent bioactive compound of immense pharmacological importance.

\section{Additional file}

Additional file 1: Supplementary data. (PDF $322 \mathrm{~kb}$ )

\section{Abbreviations}

A-549 cells: Human lung carcinoma epithelial cells; ADP: Adenosine diphosphate; DMEM: Dulbecco's modified Eagle's medium; DTT: Dithiothreitol; EDTA: Ethylenediaminetetraacetic acid; FBS: Fetal bovine serum; KPB: Potassium phosphate buffer; MTT: 3-(4,5-Dimethylthiazol-2-yl)2,5-diphenyltetrazolium bromide) tetrazolium; NCCS: National Centre for Cell Science; PBS: Phosphate buffer saline; PMSF: Phenylmethylsulfonyl fluoride; SCF: Sea-star coelomic fluid; SDS-PAGE: Sodium dodecyl sulfate polyacrylamide gel electrophoresis; VWF: von Willebrand factor

\section{Acknowledgements \\ The authors are grateful to Mr. Gurudas and Mr. Santosh (lifeguards of South Goa beaches) for their unconditional help in collection and release of the sea-stars. \\ Reprint request to be received by Dr. Dibakar Chakrabarty, Department of Biological Sciences, BITS Pilani K K Birla Goa campus, NH 17/B, Zuarinagar -403726, Goa, India. Phone: +919730258079, email: \\ dibakarchakrabarty@goa.bits-pilani.ac.in.}

\section{Funding}

The authors are grateful to Birla Institute of Technology and Science, Pilani, for partial support of this study in the form of a Seed-Grant to DC. The study also partially benefitted from a Department of Biotechnology sponsored project
(BT/PR5713/BRB/10/1112/2012). MB was supported by the DST-INSPIRE fellowship (IF130142).

\section{Availability of data and materials}

The dataset(s) supporting the conclusions of this article is (are) included within the article (and in the supplementary data). The authors can be contacted for any additional supporting data required by the journal.

\section{Authors' contributions}

$M B, D C$, and $A S$ participated in the design of this research and performed the data analysis. MB conducted all the experiments. MB, DC, and AS wrote the manuscript. All authors read and approved the final manuscript.

\section{Ethics approval and consent to participate}

The authors declare that no animal was sacrificed for this study. Blood for platelet aggregation studies was withdrawn under medical supervision with prior consent from the volunteers.

Human Ethical Approval for the project titled "Study of Hemotoxic and Cytotoxic Agents from Sea star (Starfish) Coelomic Fluid" via approval number IHEC-43/17-1 was obtained from Institute Human Ethical Committee (IHEC) BITS, Pilani (Birla Institute of Technology and Science-Pilani).

The sea-star (starfish) used in this study is Astropecten indicus as identified by the Zoological Survey of India, Chennai, India.

\section{Competing interests}

The authors declare that they have no competing interests.

\section{Publisher's Note}

Springer Nature remains neutral with regard to jurisdictional claims in published maps and institutional affiliations.

Received: 11 October 2017 Accepted: 7 May 2018

Published online: 25 May 2018

\section{References}

Allshire, A., Anoopkaumar-Dukie, S., Carey, J., Conere, T., O'Sullivan, E., \& van Pelt F. (2005). Resazurin assay of radiation response in cultured cells. The British Journal of Radiology, 78, 945-947. https://doi.org/10.1259/bjr/54004230.

Amini, E., Nabiuni, M., Baharara, J., Parivar, K., \& Asili, J. (2014). Hemolytic and cytotoxic effects of saponin like compounds isolated from Persian gulf brittle star (Ophiocoma erinaceus). J Coast Life Med, 2(8), 614-620. https://doi.org/ 10.12980/JCLM.2.2014JCLM-2014-0056.

Bordbar, S., Anwar, F., \& Saari, N. (2011). High-value components and bioactives from sea cucumbers for functional foods-A review. Marine Drugs, 9, 17611805. https://doi.org/10.3390/md9101761.

Bradford, M. M. (1976). A rapid and sensitive method for the quantitation of microgram quantities of protein utilizing the principle of protein-dye binding. Analytical Biochemistry, 72, 248-254. https://doi.org/10.1016/00032697(76)90527-3.

Cardoso, M., Costa, R., \& Mano, J. (2016). Marine origin polysaccharides in drug delivery systems. Marine Drugs, 14, 34. https://doi.org/10.3390/md14020034.

Chakrabarty, D., Datta, K., Gomes, A., \& Bhattacharyya, D. (2000). Haemorrhagic protein of Russell's viper venom with fibrinolytic and esterolytic activities. Toxicon, 38, 1475-1490. https://doi.org/10.1016/S0041-0101(99)00243-3.

Chamundeeswari (2012). Exploration of potential antimicrobial activity of sea star Astropecten indicus. J. Appl. Pharm. Sci. https://doi.org/10.7324/JAPS.2012. 2716.

Chanda, C., Sarkar, A., \& Chakrabarty, D. (2016). Thrombolytic protein from cobra venom with anti-adhesive properties. Archives of Biochemistry and Biophysics, 590, 20-26. https://doi.org/10.1016/j.abb.2015.11.006.

Chanda, C., Sarkar, A., Sistla, S., \& Chakrabarty, D. (2013). Anti-platelet activity of a three-finger toxin (3FTx) from Indian monocled cobra (Naja kaouthia) venom. Biochemical and Biophysical Research Communications, 441, 550-554. https:// doi.org/10.1016/j.bbrc.2013.10.125

Costa-Neto, E. M. (2005). Animal-based medicines: Biological prospection and the sustainable use of zootherapeutic resources. An. Acad. Bras. Ciênc., 77. https:// doi.org/10.1590/S0001-37652005000100004.

Dong, G., (2011). Chemical Constituents and Bioactivities of Starfish - Chemistry \& Biodiversity - Wiley Online Library [WWW Document]. URL http:// onlinelibrary.wiley.com/doi/10.1002/cbdv.200900344/full (accessed 4.3.17). 
Engelmann, B., \& Massberg, S. (2012). Thrombosis as an intravascular effector of innate immunity. Nature Reviews. Immunology, 13, 34-45. https://doi.org/10. 1038/nri3345.

Ferguson, J. C. (1964). Nutrient transport in starfish. I. Properties of the COELOMIC fluid. The Biological Bulletin, 126, 33-53. https://doi.org/10.2307/1539415.

Golebiewska, E. M., \& Poole, A. W. (2015). Platelet secretion: From haemostasis to wound healing and beyond. Blood Reviews, 29, 153. https://doi.org/10.1016/j. blre.2014.10.003.

Italiano, J. E., Richardson, J. L., Patel-Hett, S., Battinelli, E., Zaslavsky, A., Short, S., Klement, G. L. (2008). Angiogenesis is regulated by a novel mechanism: Proand antiangiogenic proteins are organized into separate platelet a granules and differentially released. Blood, 111, 1227-1233. https://doi.org/10.1182/ blood-2007-09-113837.

Key, N. S., Makris, M., \& Lillicrap, D. (2016). Practical hemostasis and thrombosis. Wiley.

Lau, W. C. (2003). Atorvastatin reduces the ability of Clopidogrel to inhibit platelet aggregation: A new drug-drug interaction. Circulation, 107, 32-37. https://doi. org/10.1161/01.CIR.0000047060.60595.CC.

Leber, T. M., \& Balkwill, F. R. (1997). Zymography: A single-step staining method for quantitation of proteolytic activity on substrate gels. Analytical Biochemistry, 249, 24-28. https://doi.org/10.1006/abio.1997.2170.

Lee, C.-C., Hsieh, H. J., Hsieh, C.-H., \& Hwang, D.-F. (2014). Antioxidative and anticancer activities of various ethanolic extract fractions from crown-ofthorns starfish (Acanthaster planci). Environmental Toxicology and Pharmacology, 38, 761-773. https://doi.org/10.1016/j.etap.2014.08.021.

Masure, S., Proost, P., Van Damme, J., \& Opdenakker, G. (1991). Purification and identification of 91-kDa neutrophil gelatinase. European Journal of Biochemistry, 198, 391-398. https://doi.org/10.1111/j.1432-1033.1991.tb16027.x.

Mercandetti, M. (2015). Wound healing and repair: Overview, types of wound healing, categories of wound healing [WWW document]. URL https:// emedicine.medscape.com/article/1298129-overview. (accessed 4.24.17).

Montaser, R., \& Luesch, H. (2011). Marine natural products: A new wave of drugs? Future Medicinal Chemistry, 3, 1475. https://doi.org/10.4155/fmc.11.118.

Newman, D., \& Cragg, G. (2014). Marine-sourced anti-cancer and cancer pain control agents in clinical and late preclinical development. Marine Drugs, 12, 255-278. https://doi.org/10.3390/md12010255.

Nurden, A., Nurden, P., Sanchez, M., Andia, I., \& Anitua, E. (2008). Platelets and wound healing. Frontiers in Bioscience, 13, 3525-3548.

Pathan, J., Martin, A., Chowdhury, R., Chakrabarty, D., \& Sarkar, A. (2015). Russell's viper venom affects regulation of small GTPases and causes nuclear damage. Toxicon, 108, 216-225.

Pathan, J., Mondal, S., Sarkar, A., \& Chakrabarty, D. (2017). Daboialectin, a C-type lectin from Russell's viper venom induces cytoskeletal damage and apoptosis in human lung cancer cells in vitro. Toxicon, 127, 11-21. https://doi.org/10. 1016/j.toxicon.2016.12.013.

Prabhu, K. (2013). Biological properties of brittle star Ophiocnemis marmorata collected from Parangipettai, southeast coast of India. J. Microbiol. Antimicrob., 5, 110-118. https://doi.org/10.5897/JMA2013.0270.

Riss, T. L., Moravec, R. A., Niles, A. L., Duellman, S., Benink, H. A., Worzella, T. J., \& Minor, L. (2016). Cell viability assays. Eli Lilly \& Company and the National Center for Advancing Translational Sciences. Retrieved from https://www. ncbi.nlm.nih.gov/books/NBK144065/.

Schillaci, D., \& Arizza, V. (2013). Echinoderm antimicrobial peptides to contrast human pathogens. Nat. Prod. Chem. Res. doi. https://doi.org/10.4172/2329-6836.1000109.

Secades, P., \& Guijarro, J. A. (1999). Purification and characterization of an extracellular protease from the fish pathogen Yersinia ruckeri and effect of culture conditions on production. Applied and Environmental Microbiology, 65, 3969-3975.

Sharmin, F., (2017). Molecular identification, micronutrient content, antifungal and hemolytic activity of starfish Asterias amurensis collected from Kobe coast, Japan [WWW document]. URL http://www.academicjournals.org/journal/AJB/ article-full-text-pdf/D74472B62537 (accessed 2.13.17).

Simon, P.E. (2015). Skin wound healing: Overview, hemostasis, inflammatory phase [WWW document]. URL https://emedicine.medscape.com/article/ 884594-overview (accessed 4.24.17).

Thao, N. P., Luyen, B. T. T., Kim, E.-J., Kang, H.-K., Kim, S., Cuong, N. X., ... Kim, Y. H. (2014). Asterosaponins from the starfish Astropecten monacanthus suppress growth and induce apoptosis in $\mathrm{HL}-60, \mathrm{PC}-3$, and SNU-C5 human cancer cell lines. Biological \& Pharmaceutical Bulletin, 37, 315-321. https://doi.org/10. 1248/bpb.b13-00705.

Vinothkumar, S., \& Parameswaran, P. S. (2013). Recent advances in marine drug research. Biotechnology Advances, 31, 1826-1845. https://doi.org/10.1016/j. biotechadv.2013.02.006.

\section{Submit your manuscript to a SpringerOpen ${ }^{\circ}$ journal and benefit from:}

- Convenient online submission

- Rigorous peer review

- Open access: articles freely available online

- High visibility within the field

- Retaining the copyright to your article

Submit your next manuscript at $\boldsymbol{\nabla}$ springeropen.com 